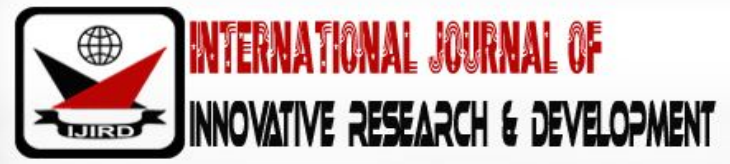

ISSN 2278 - 0211 (Online)

\section{The Effects of Hydromethanolic Extracts of Uncoated and Coated Seeds of Garcinia Kola on the Sexual Behaviour of Male Wistar Rats}

Dr. Chibuike Obiandu
Lecturer, Department of Human Physiology, Faculty of Basic Medical Sciences, College of Health
Sciences, University of Portharcourt, Nigeria
Dr.Ologhaguo Macstephen Adienbo
Senior Lecturer, Department of Human Physiology, Faculty of Basic Medical Sciences, College of
Health Sciences, University of Portharcourt, Nigeria
Arthur Nwafor Chuemere
Professor, Department of Human Physiology, Faculty of Basic Medical Sciences, College of Health
Sciences, University of Portharcourt, Nigeria

\begin{abstract}
:
Male sexual dysfunctions which presents in various forms such as erectile dysfunction,premature ejaculation and orgasmic disorders etc. are on the rise.As a result, various treatment options including medicinal plants are been investigated to determine their aphrodisiac potentials. In this study,the extracts of the uncoated seed (pulp) and coated seed of Garcinia kola were assessed for their aphrodisiac properties.Garcinia kola seeds in coated and uncoated forms were separately chopped into smallerpieces,dried and then blended to fine powder.Extraction was done using hydromethanol (1:4) as solvent. Eight (8) male rats were randomly assigned into five (5) groups. Group one 1 which served as control received distilled water. Group two 2and group 3 received $100 \mathrm{mg} / \mathrm{kg}$ and $200 \mathrm{mg} / \mathrm{kg}$ of the uncoated seed extracts while group 4 and group 5 received $100 \mathrm{mg} / \mathrm{kg}$ and $200 \mathrm{mg} / \mathrm{kg}$ of the coated seed extracts respectively.The extracts were orally administered daily for 30 and 60 days.

Tests forsexual behavior were done by assessing the mounting latency(ML), mounting frequency(MF),intromission latency(IL), intromission frequency(IF), ejaculation latency(EL), ejaculation frequency(EF) and post ejaculatory interval(PEI).

Results obtained showed that precopulatory behaviors such as chasing,sniffing and nosing were increased in the test males.The ML and IL were significantly reduced after30 and 60 daystreatment at higher doses $(200 \mathrm{mg} / \mathrm{kg})$ of both extractswhereas, the MF and IF were significantly increased in 30 days at higher doses of both extracts, while the IF was significantly increased after 60 days at higher dose of the coated seed.The EL was also significantly increased at the higher doses of both extracts while the PEI was significantly reduced at higher dose of the coated seed. It was concluded that Garcinia kola seed extracts (uncoated and coated) could enhance sexual activity by improving sexual arousability (libido), vigour and potency,as well as prolongation of coital period.However, the consumption of Garcinia kola seed for long-term basis ( 60 days) for the purpose of sustaining sexual vigour in males may add no physiological value.
\end{abstract}

Keyword: Garcinia kola, hydromethanol, sexual behaviour, aphrodisiac, erectile dysfunction

\section{Introduction}

Sexual health and function are inevitably, very important determinants of the quality of an individual's life (Suchita, et al.,2013).Sexual activity is universally recognized as essential component of a normal,healthy lifestyle and wellbeing (Singh, et al.,2013).However,the regular inability of a couple to indulge in a successful sexual intercourse is on the increase worldwide(Yakubu, etal.,2007).Reproduction in human begins with the copulation of a male and a female which results in fertilization(Fullick et al.,1994).For this process to be effective and satisfactory,the copulatory organ in the male,the penis and 
factors relating to erection must function normally.Inability to perform this function is regarded as sexual dysfunction. Sexual dysfunction is more prevalent in males than females and has prompted increased interests in research into male sexual difficulties (Guay et al.,2003).Male sexual dysfunction could present in various forms such as arousal difficulty (poor libido), orgasmic disorders, premature ejaculation,retarded or inhibited ejaculation and erectile dysfunction, etc. (Yakubu et al,2007); which may not threaten physical health but may present heavy psychological toll,causing depression,anxiety and feelings of inadequacy(Salmon et al.,1983).It can be treated using aphrodisiacs which are substances that enhances sexual drive and/ or sexual pleasure(Yakubu, et al.,2007).Enhanced sexual behavior may lead to increased relationship satisfaction and improved self esteem in humans(Singh et al.,2010).

The rising incidence of male sexual dysfunction has necessitated more and quick search into plants with aphrodisiac effects(Yakubu et al.,2007).Several medicinal plantextracts such as Asparagus racemosus (Wani et al.,2011),Anacyclus pyrethrum DC (Sharma et al.,2009) and Butea frondosa koen ex Roxb(Ramachandran et al.,2004) have been investigated and found to possess aphrodisiac properties.Although,studies have been done to investigatethe aphrodisiac potential of Garcinia kola,contradictions exist in their reported findings. Yakubu et al.(2012), reported that the acclaimed aphrodisiac properties of Garcinia kolawere untrue while Ralebona etal. (2012), reported that the Garcinia kola extracts demonstrated significant aphrodisiac properties.These studies were done using the uncoated seed(pulp)of Garcinia kola. But some consumers of Garcinia kola have claimed that the coated seed of Garcinia kola were more effective in traditional remedies for the treatment of male sexual disorders such as erectile dysfunction.

This study was carried out with the objective to investigate the aphrodisiac potential of the hydromethanolic extract of the uncoated and coated seed ofGarcinia kola.

\section{Materials and Methods}

\subsection{Animal Models}

Adult male rats bred in the animal house of the Faculty of Basic Medical Sciences, University of Port Harcourt were used for this study. They were chosen at random, placed in neat cages and allowed two weeks to acclimatize. They were nurtured under standard conditions which entailed exposure to 12-hour light and 12-hour dark schedules, with surrounding temperature of $25^{\circ \mathrm{c}} \pm 2^{\circ \mathrm{cc}}$ and relative humidity of $55-65 \%$. They had free access to water and feeds (commercially available rat chows produced by Top feeds Nigeria Limited). The rats were handled with optimum care and their cages were cleaned as well as beddings changed daily.

The experiments were carried out in conformity with standard institutional guidelines (American Physiological Society, 2002).This study was approved by the ethical committee of the College of Health Sciences, University of Port Harcourt.

\subsection{Preparation of Plant Extract}

Garcinia kola seeds were purchased from a local vendor in Rivers state, Nigeria. They were later authenticated at the herbarium in the department of Plant Science and Biotechnology, University of Port Harcourt, Nigeria. The outer coat of some of the seeds were removed and the uncoated seeds were sliced to smaller pieces and dried.Also, some coated seeds were washed, chopped into smaller pieces and dried.The two forms were separately blended to fine powder. Hydromethanol (20\%: $80 \%$ ) was used as solvent in the extraction which was done with the soxhlet apparatus at $60^{\circ} \mathrm{C}-70^{\circ} \mathrm{C}$ giving rise to a solution containing the extracts. The solution was filtered and the filtrate was concentrated to a semi solid form under reduced pressures of $60^{\circ} \mathrm{C}$ using the rotary evaporator.The extract yield was weighed and stored in the refrigerator at $4^{\circ} \mathrm{C}$.

Measured quantity of the extracts were dissolved in distilled water to obtain $100 \mathrm{mg} / \mathrm{ml}$ and $200 \mathrm{mg} / \mathrm{ml}$ of the extract for animal treatments.

\subsection{Experimental Design}

The rats were randomly assigned into five (5) groups. Each group contained 8 rats. Group I served as control and received distilled water. Group 2 and group 3 received $100 \mathrm{mg} / \mathrm{kg}$ body weight (bw) and $200 \mathrm{mg} / \mathrm{kg}$ bw of the hydromethanolic extract of theuncoated seeds respectively. Group 4 and group 5 received $100 \mathrm{mg} / \mathrm{kg}$ bw and $200 \mathrm{mg} / \mathrm{kg}$ bw of the hydromethanolic extract of the coated seeds respectively.

Extracts were administered as single daily dose through the oral route for 30 days and 60 days duration. The sexual behavior test was done on day 30 and on day 60 .

\subsection{Sexual Behavior Test}

The methods adopted in sexual behavior test of male rats in this study has been described in previous studies (Dewsbury et al., 1970; Madlafousek et al., 1971) and modified by Yakubu et al.,2007.

Only female rats on estrus were allowed to mate with the males. The test females were artificially brought into estrus (heat) by administration of oral estradiol benzoate at the dose of $10 \mu \mathrm{g} / 100 \mathrm{~g}$ bw and progesterone $0.5 \mathrm{mg} / 100 \mathrm{~g} \mathrm{bw}$ subcutaneously 48hours and 4hours respectively before experiment (Yakubu et al., 2007). 
Eight (8) male rats from each group were monitored for sexual behavior for a period of 30 minutes on day 30 and also on day 60 . Sexual behavior experiments were carried out during the first 4hours of the 12 hours dark cycle and 3hours after extract administration.

First, the test male rat was introduced into the observation cage with dimension $(56 \times 35 \times 31 \mathrm{~cm})$ as described by Adienbo et al. (2013) and allowed a period of 10 minutes for adaptation before the stimulus female was introduced. Only active (hopping and darting females) were used. Any dull, reclusive and poorly motivated stimulus female rat were exchanged during the testing sessions in order to keep the sexual stimulation of the male high enough.

The receptive female and male rats were observed from a corner for precopulatory and copulatory behaviours. The parameters used in measurement of sexual behavior includes:

1. Mount latency (ML): time from the entrance of the female to the first mount.

2. Intromission latency (IL): time from the entrance of the female to the first intromission (vaginal penetration)

3. Ejaculation latency (EL) : time from the first intromission to ejaculation

4. Post Ejaculatory interval (PEI): time from ejaculation to the first intromission of the second copulatory series.

5. Mount frequency (MF): number of mounts preceding ejaculation.

6. Intromission frequency (IF): number of intromissions preceding ejaculation.

7. Ejaculation frequency (EF): number of ejaculations in a copulatory series.

\subsection{Statistical Analysis}

Results were analyzed using Statistical Package for Social Sciences (SPSS) version 20.0 and expressed as Mean \pm SEM. The significance of difference between means was determined by Least Significance Difference (LSD) and the results were regarded as significant at $\mathrm{p}<0.05$.

\section{Result}

\subsection{Result Presentation}

As observed in this study, the female rats displayed features which confirmed that they were in the physiological state of estrus. Once introduced to the test males in the observation cage, they took quick springy leaps, made a short run (hopping and darting) with wiggling ears and then presented the posterior to the male rats in a lordotic pattern.

The treated male rats demonstrated increased precopulatory behaviours (chasing, sniffing and nosing) which culminated in mounting. There was increased genital grooming as well.

The result for sexual behavior tests are as presented in tables 1 to 4 .

\begin{tabular}{|c|c|c|c|c|}
\hline \multirow{2}{*}{ Group } & \multicolumn{2}{|c|}{ Mounting Latency(sec) } & \multicolumn{2}{c|}{ Mounting Frequency(n) } \\
\cline { 2 - 4 } & $\mathbf{3 0}$ days & $\mathbf{6 0}$ days & $\mathbf{3 0}$ days & $\mathbf{6 0}$ days \\
\hline $\begin{array}{c}\text { Group1 } \\
\text { (Control) }\end{array}$ & $63.63 \pm 6.92$ & $56.63 \pm 4.75$ & $10.25 \pm 2.30$ & $10.50 \pm 1.50$ \\
\hline $\begin{array}{c}\text { Group2 :Uncoated seed } \\
\text { extracts (100mg/ kg) }\end{array}$ & $54.13 \pm 5.97$ & $50.63 \pm 4.01$ & $11.00 \pm 1.78$ & $9.88 \pm 1.97$ \\
\hline $\begin{array}{c}\text { Group3 :Uncoated seed } \\
\text { extracts (200mg/ kg) }\end{array}$ & $38.25 \pm 3.47^{\ddagger}$ & $33.00 \pm 2.46^{\ddagger \mathrm{a}}$ & $19.50 \pm 2.16^{\ddagger \mathrm{a}}$ & $14.00 \pm 1.70^{\mathrm{d}}$ \\
\hline $\begin{array}{c}\text { Group 4:Coated seed extracts } \\
\text { (100mg/ kg) }\end{array}$ & $54.25 \pm 7.14$ & $51.88 \pm 4.75$ & $10.13 \pm 1.74$ & $9.63 \pm 1.65$ \\
\hline $\begin{array}{c}\text { Group5:Coated seed extracts } \\
(200 \mathrm{mg} / \mathrm{kg})\end{array}$ & $45.38 \pm 3.96^{*}$ & $35.75 \pm 2.37 \neq \mathrm{b}$ & $17.25 \pm 1.92^{* \mathrm{a}}$ & $14.88 \pm 1.75$ \\
\hline
\end{tabular}

Table 1: Effect of Hydromethanolic Seed Extracts of Garcinia Kola on Mounting Behaviours in Male Wistar Rats Values expressed as Mean \pm SEM. $n=8$.Significant at $[\ddagger ; a(P<0.01)]$ and $[* ; b ; d(P \varangle 0.05)]$ when compared with control, lower dose and between 30 and 60 days respectively.

\begin{tabular}{|c|c|c|c|c|}
\hline \multirow{2}{*}{ Group } & \multicolumn{2}{|c|}{ Intromission Latency(sec) } & \multicolumn{2}{c|}{ Intromission Frequency(n) } \\
\cline { 2 - 5 } & 30 days & 60 days & 30 days & 60 days \\
\hline $\begin{array}{c}\text { Group1 } \\
\text { (Control) }\end{array}$ & $60.63 \pm 6.19$ & $61.38 \pm 3.57$ & $4.75 \pm 1.01$ & $6.38 \pm 1.43$ \\
\hline $\begin{array}{c}\text { Group2 :Uncoated seed } \\
\text { extracts (100mg/ kg) }\end{array}$ & $57.00 \pm 6.04$ & $54.75 \pm 4.84$ & $6.13 \pm 1.29$ & $8.50 \pm 1.61$ \\
\hline $\begin{array}{c}\text { Group3 :Uncoated seed } \\
\text { extracts (200mg/ kg) }\end{array}$ & $42.00 \pm 6.01^{* b}$ & $42.00 \pm 3.96^{\ddagger}$ & $14.25 \pm 1.71^{\ddagger a}$ & $10.25 \pm 1.80$ \\
\hline Group 4:Coated seed & $57.13 \pm 6.08$ & $55.75 \pm 4.06$ & $6.25 \pm 1.11$ & $9.13 \pm 1.85$ \\
\hline
\end{tabular}




\begin{tabular}{|c|c|c|c|c|}
\hline extracts (100mg/ kg) & & & \\
\hline $\begin{array}{c}\text { Group5:Coated seed } \\
\text { extracts (200mg/ kg) }\end{array}$ & $39.75 \pm 5.96 * \mathrm{~b}$ & $41.00 \pm 3.95^{\ddagger \mathrm{b}}$ & $14.00 \pm 1.89 \ddagger \mathrm{a}$ & $13.00 \pm 1.96 \ddagger \mathrm{b}$ \\
\hline
\end{tabular}

Table2: Effect of Hydromethanolic Seed Extracts of Garcinia Kola on Intromission Behaviours in Male Wistar Rats Values expressed as Mean \pm SEM. $\mathrm{n}=8$.Significant at $[\ddagger ; \mathrm{a}(\mathrm{P}<0.01)]$ and $[* ; \mathrm{b}(\mathrm{P} \varangle 0.05)]$ when compared with control and Lower doses respectively.

\begin{tabular}{|c|c|c|c|c|}
\hline \multirow{2}{*}{ Group } & \multicolumn{2}{|c|}{ Ejaculation Latency(sec) } & \multicolumn{2}{c|}{ Ejaculation Frequency(n) } \\
\cline { 2 - 5 } & $\mathbf{3 0}$ days & $\mathbf{6 0}$ days & $\mathbf{3 0 \text { days }}$ & $\mathbf{6 0}$ days \\
\hline $\begin{array}{c}\text { Group1 } \\
(\text { Control })\end{array}$ & $155.63 \pm 4.87$ & $147.38 \pm 4.54$ & $1.25 \pm 0.25$ & $1.25 \pm 0.25$ \\
\hline $\begin{array}{c}\text { Group2 :Uncoated seed extracts } \\
(100 \mathrm{mg} / \mathrm{kg})\end{array}$ & $166.38 \pm 8.27$ & $152.38 \pm 6.41$ & $1.13 \pm 0.35$ & $1.13 \pm 0.30$ \\
\hline $\begin{array}{c}\text { Group3 :Uncoated seed extracts } \\
(200 \mathrm{mg} / \mathrm{kg})\end{array}$ & $183.00 \pm 6.68^{*}$ & $\begin{array}{c}176.00 \pm 10.76 \\
* \mathrm{~b}\end{array}$ & $1.13 \pm 0.40$ & $1.00 \pm 0.33$ \\
\hline $\begin{array}{c}\text { Group 4:Coated seed extracts } \\
(100 \mathrm{mg} / \mathrm{kg})\end{array}$ & $161.50 \pm 4.15$ & $159.63 \pm 3.79$ & $1.00 \pm 0.27$ & $1.25 \pm 0.31$ \\
\hline $\begin{array}{c}\text { Group5:Coated seed extracts } \\
(200 \mathrm{mg} / \mathrm{kg})\end{array}$ & $181.88 \pm 3.98^{*}$ & $182.25 \pm 4.93^{\ddagger}$ & $1.13 \pm 0.35$ & $1.00 \pm 0.33$ \\
\hline
\end{tabular}

Table3: Effect of Hydromethanolic Seed Extracts of Garcinia Kola on Ejaculation Behaviours in Male Wistar Rats Values expressed as Mean \pm SEM. $n=8$.Significant at $\left[{ }^{\ddagger}(\mathrm{P}<0.01)\right]$ and $[* \mathrm{~b}(\mathrm{P}<0.05)]$ when compared with control and lower doses respectively

\begin{tabular}{|c|c|c|}
\hline Group & \multicolumn{2}{|c|}{ Post ejaculatory interval(sec) } \\
\cline { 2 - 3 } & $\mathbf{3 0}$ days & $\mathbf{6 0}$ days \\
\hline $\begin{array}{c}\text { Group1 } \\
\text { (Control) }\end{array}$ & $186.88 \pm 11.68$ & $179.38 \pm 11.18$ \\
\hline Group2 :Uncoated seed extracts $(100 \mathrm{mg} / \mathrm{kg})$ & $171.38 \pm 11.68$ & $162.38 \pm 11.15$ \\
\hline Group3 :Uncoated seed extracts $(200 \mathrm{mg} / \mathrm{kg})$ & $167.13 \pm 12.56$ & $162.25 \pm 11.69$ \\
\hline Group 4:Coated seed extracts $(100 \mathrm{mg} / \mathrm{kg})$ & $168.13 \pm 11.85$ & $160.88 \pm 11.43$ \\
\hline Group5:Coated seed extracts $(200 \mathrm{mg} / \mathrm{kg})$ & $150.50 \pm 5.51^{*}$ & $160.13 \pm 11.40$ \\
\hline
\end{tabular}

Table4: Effect Of Hydromethanolic Seed Extracts of Garcinia Kola on Post Ejaculatory Interval on Male Wistar Rats Values expressed as Mean \pm SEM. $n=8$.Significant at $[*(P<0.05)]$ when compared with control

\subsection{Result analysis}

In 30 and 60 days, extracts of the low dose of $100 \mathrm{mg} / \mathrm{kg}$ (group 2), higher dose of $200 \mathrm{mg} / \mathrm{kg}$ (group 3) of theuncoated seeds and low dose of $100 \mathrm{mg} / \mathrm{kg}$ (group 4), higher dose of $200 \mathrm{mg} / \mathrm{kg}$ (group 5) of the coated seed of Garcinia kola were respectively administered.

Table 1 showed that,following 30 days extract administration,the reduction in ML and the increase in MF in group3 were found to be highly significant $(\mathrm{P}<0.01$ ) whereas, the reduction in ML and the increase in MF in group 5 were significant at $\mathrm{P}<0.05$, when compared with control.

The higher dose $(200 \mathrm{mg} / \mathrm{kg}$ ) of the uncoated seed (group 3) caused more significant $(\mathrm{P} \varangle 0.05)$ reductions in $\mathrm{ML}$ when compared with lower dose $(100 \mathrm{mg} / \mathrm{kg}$ ) (group 2). For the MF, higher doses of $200 \mathrm{mg} / \mathrm{kg}$ in group3 and group5 caused significant $(\mathrm{P}<0.01)$ increase when compared with lower doses of $100 \mathrm{mg} / \mathrm{kg}$ of extract in group 2 and group 4 .

Also, following 60 days administration of extracts, the $\mathrm{ML}$ was reduced significantly $\mathrm{P} \varangle 0.01$ in groups 3 and 5 but the differences in MF were not significant $(\mathrm{P} \varangle 0.05)$ when all were compared between control and tests groups.

The Differences in ML were highly significant at $\mathrm{P}<0.01$ and $\mathrm{P}<0.05$ between groups ( 2 and 3 ) and between groups ( 4 and 5) respectively. There were also significant $(\mathrm{P}<0.05)$ decrease in MF in group 3 following 60 days administration when compared to 30 days.

In table 2, after 30 days administration of extracts, the IL was significantly $(\mathrm{P} \varangle 0.05)$ reduced while the IF was significantly $(\mathrm{P}<0.01)$ increased for groups 3 and 5 when compared with control. There were also significant $(P<0.05)$ reductions in IL when higher doses $(200 \mathrm{mg} / \mathrm{kg}$ ) of group 3 and 5 were compared with lower doses (100mg/ $\mathrm{kg})$ of group 2 and 4 respectively.

After 60 days, the IL was significantly reduced $(\mathrm{P}<0.01)$ for groups 3 and 5 while the IF was significantly $\mathrm{P} \varangle 0.01$ increased for group 5 when compared with controls.

The IL was significantly reduced $\mathrm{P} \varangle 0.05$ when higher dose $(200 \mathrm{mg} / \mathrm{kg})$ of group 5 were compared with lower dose $(100 \mathrm{mg} / \mathrm{kg})$ of group 4 , while the IF was significantly $(\mathrm{P}<0.05)$ increased when higher dose $(200 \mathrm{mg} / \mathrm{kg})$ of group5 were compared with lower dose (100mg/ kg) of group 4 . 
Table 3 showed that, after 30 days administration of extract, the EL was significantly $(\mathrm{P} \varangle 0.05)$ increased in groups 3 and 5, whereas, the differences in EF were not statistically significant when compared with control. After 60 days, the EL was found to be significantly increased at $\mathrm{P} \varangle 0.05$ and $\mathrm{P}<0.01$ for groups 3 and 5 respectively, when compared with control.

Also, the higher dose of $200 \mathrm{mg} / \mathrm{kg}$ (group 3) significantly increased $(\mathrm{P} \varangle 0.05)$ the EL compared to lower dose of $100 \mathrm{mg} / \mathrm{kg}$ (group 2) after 60 days administration. The differences in EF after 60 days was not statistically significant $(\mathrm{P}<0.05)$ when compared with control.

In table 4, The PEI was found to be significantly reduced in group 5 when compared with control, when extracts were administered for 30 days. In 60 days, there were no statistically significant differences observed for PEI.

\section{Discussion}

This study was done to evaluate the effects of coated and uncoated seed extracts of Garcinia kolaon sexual behavior in male wistar rats. This study also sought to compare the acclaimed aphrodisiac effects of both the uncoated andcoated seed of Garcinia kola.

Any medicinal plant with aphrodisiac potentials should produce significant increase in the MF and IF and a decrease in the ML and IL which are all indicators of sexual arousability, motivation and sexual vigour (Ratnasooriya et al, 2000; Yakubu et al, 2005). Also, Meisel and Sachs(1994),stated that the MF and IF are important measures of both libido and potency. In a similar report, Yakubu(2006), also stated that significant decrease in ML and IL are indicators of sustained increase in sexual activity and aphrodisiac property in a plant extract while Agmo (1999), affirmed that the ML is generally believed to be an important index of sexual motivation.

In this study, it was observed that the Garcinia kola seed extracts (uncoated and coated) enhancedsexual activity in male rats by improving sexual arousability (libido) and potency,as evidenced in its abilityto increase the MF and IF while decreasing the ML and IL.These findings are in agreement with the report of Ralebona et al.(2012), who stated that the $200 \mathrm{mg} / \mathrm{kg}$ body weight extract of Garcinia kola seed caused a highly significant ( $\mathrm{P}<0.01)$ increase in the MF and IF.

Although, there was no significant alteration of the EF, but the EL was increased by both the uncoated and coated seed extracts.

The observed increase in EL implies that the extracts caused delay in ejaculation thereby prolonging coital period and improving sexual activity.The prolongation in duration of coitus observed in this study suggest that the seed extract could reduce the incidence of early or premature ejaculation.

The PEI is a parameter used to measure the rate of recovery from exhaustion in early mating series (Tajuddin, et al 2004).

The PEI may not have been reported previously for Garciniakola seed. In this study, the coated seed extracts causedsignificant $(\mathrm{p}<0.05)$ reductions in PEI when compared with control.

Yakubu and Quadri (2012), studied the effects of 25, 50 and 100mg/ kg respectively of the seed extract (uncoated) of Garcinia kola on sexual behavior of male rats and concluded that Garcinia kola seeds did not have sex enhancing potentials. However, the findings in the present study suggest otherwise. At $100 \mathrm{mg} / \mathrm{kg}$ bw,the extract of Garcinia kola seed did not show any significant improvement in sexual activity while at $200 \mathrm{mg} / \mathrm{kg}$ body weight dose, there was enhancement in sexual behaviour.

A dose dependent relationship exists.The low dose $(100 \mathrm{mg} / \mathrm{kg})$ of both the uncoated and coated seed extract did not cause any significant difference in mating behavior of male rats, while the higher doses showed enhancement.This observation may imply that, the effective dose for eliciting aphrodisiac effect of the uncoated and coated seed of Garcinia kola ranges from $200 \mathrm{mg} / \mathrm{kg}$ body weight in agreement with Ralebona et al. (2012), who reported that, $200 \mathrm{mg} / \mathrm{kg}$ of the uncoated seed of Garcinia kola caused significant aphrodisiac effects.Long-term (60 days) administration of the extracts did not improve mating behavior above a 30-day period.Therefore, habitual long-term consumption of Garcinia kola seed may not confer any benefits or add value to sustained sexual vigour in males.There were close similarities between the actions of the uncoated and coated seed as they equally caused improvement of the various sexual behavioural parameters.The coated seed extract inexplicably,caused a significant decrease inthe PEI after 30 days treatment,whereas, the uncoated seed did not. This suggest the possibility of an interaction between the uncoated seed (pulp) and the seed coat in enhancing the PEI.

The exact mechanism of action of Garcinia kola seed in enhancing sexual behavior in male rats is inconclusive.Yakubu et al.(2007), stated that a medicinal plant with aphrodisiac potential should be able to cause changes leading to a statistically significant increase in testosterone level or be capable of stimulating the cavernous nerve which will normally lead to increase in nitric oxide and cyclic guanosine phosphate (cGmp) signaling,in corpus cavernosal smooth muscle relaxation. However, increased serum testosterone levels have been reported with administration ofGarcinia kola seed extracts [Ovuakporaye and Odokuma (2014); Ralebona et al.,(2012)].

\section{Conclusion/ Recommendation}

The seed extracts of Garcinia kola (uncoated and coated) are equally effective in enhancing sexual behavior in male rats at a higher dose of $200 \mathrm{mg} / \mathrm{kg}$ body weight. The low dose of $100 \mathrm{mg} / \mathrm{kg}$ did not prove to be significantly effective in enhancing male sexual functions. The consumption of Garcinia kola seed for long-term basis (60 days) for the purpose of sustaining sexual vigour in males adds no physiological value. 
It is however recommended that further studies be carried out to investigate the exact mechanism of action of Garcinia kola seed in enhancing sexual behavior in male wistar rats.

\section{References}

i. Adienbo, OM., Nwafor,A and Ronami SO. (2013). Effect of Hydromethanolic extract of xylopia aethopica on sexual behavior in male wistar rats. International journal of Advanced Biological Research.1(9):1078 - 1085.

ii. Agmo, A. (1999). Sexual motivation-an enquiry into events determining the occurrence of sexual behavior. Behavioural brain research. 105:129-150.

iii. American Physiological Society. (2002). Guiding principles for research involving animals and human beings. American journal of physiology, regulatory, integrative and comparative physiology. 283: 281 - 283

iv. Dewsbury DA and Davis HN (Jr). (1970). Effect of Reserpine on the copulatory behavior of male rats. Physiology and Behaviour. 5: 1331 - 1333.

v. Fullick, A. (1994). Biology. Heinemann Advanced Science. Oxford. pp. 332.

vi. Guay, AT., Spark, RF.,Bansal,S., Cunningham, GR., Goodman, NF., Nankin, HR., Petak, SM and Perez, JB. (2003). American Association of clinical endocrinologist: medical guidelines for clinical practice for the evaluation and treatment of male sexual dysfunction. A couple's problem. Endocrinepractice .9 (1): 78-95.

vii. Madlafousek J., Hliňak, Z and Pař́tzek J. (1971). Sexual Behaviour of male rats sterilized by cadmium. Journal of reproduction and fertility.26:189-196

viii. Meisel RL and Sachs BD. (1994). The physiology of male sexual behavior. IN: Knobil E and Neil JD (Eds). The physiology of reproduction. $2^{\text {nd }}$ Edn, Raven press, New York. 2:3-105.

ix. Ovuakporaye, SI and Odokuma,EJ (2014). The effect of Garcinia Kola (Bitter kola) on Testosterone and the Histology of the testes in male Albino wistar rats. Journal of Sciences and multidisciplinary Research.6(2):158-164.

x. Ralebona,N.,Sewani-Rusike, CR and Nkeh-Chungag BN. (2012). Effects of ethanolic extract of Garcinia kola on sexual behaviour and sperm parameters in male wistar rats. African Journal of pharmacy and pharmacology. 6(14):1077-1082.

xi. Ramachandran S., Sridhar Y., Sam SK., Saravanan M., Leonard JT., Anbalagan N and Sridhar SK. (2004). Aphrodisiac activity of Butea frondosa koen ex Roxb extract in male rats. Phytomedicine.11(2-3):165-8.

xii. Ratnasooriya WD and MG Dharmasiri. (2000). Effects of Terminalia catappa seeds on sexual behavior and fertility of male rats. Asian Journal of Andrology 2:213-219.

xiii. Salmon, P.H.(1983). Psychosexual dysfunction in chronic renal failure: An overview. Proc EDTNA, 12,209-212.

xiv. Sharma V., Thakur M., Chauhan N S., Dixit VK. (2009). Evaluation of the Anabolic, Aphrodisiac and Reproductive Activity of Anacyclus pyrethrum DC in male rats. Austrian journal of pharmaceutical sciences. 77:97-110.

xv. Singh, B., Gupta, V., Bansal P., Singh, R., and Kumar, D. (2010). Pharmacological potential of plant used as aphrodisiacs. International Journal of Pharmaceutical sciences review and research. 5(1):104-113.

xvi. Singh, R., Ali, A., and Singh S. (2013). Current status of Indian medicinal plants with aphrodisiac potential. Pharmacologia.4 (4):276-284.

xvii. Suchita, M., Praveen, K.D. (2013).A current review of plants possessing aphrodisiac activity. International Journal of Inventions in Pharmaceutical Sciences .1(3):167-173.

xviii. Tajuddin AS, Latif A and Quasmi IA. (2004). Effect of 50\% ethanolic extract of Syzygium aromaticum (L). merr. \& Perry. (clove) on sexual behavior of normal male rats. BMC complementary alternative medicine. 4:17-24.

xix. Wani JA., Achur R.N and Nema RK. (2011). Phytochemical screening and aphrodisiac activity of Asparagus racemosus. International Journal of Pharmaceutical Sciences and Drug Research. 3(2):112-115.

xx. Yakubu , MT. (2006). Aphrodisiac potentials and toxicological evaluation of aqueous extract of Fadogia agrestis Schweininf ex. Hiern) stem in male rats. Ph.D. Thesis. University of Ilorin, Ilorin Nigeria.

xxi. Yakubu MT., AkanJi MA and Oladiji AT. (2005). Aphrodisiac potentials of aqueous extract of fadogia agrestisschweinf. ex hiern stem in male albino rats. Asian journal of Andrology 7(4):399-404.

xxii. Yakubu, MT., Akanji, MA., and Oladiji, AT. (2007). Male sexual dysfunction and methods used in assessing medicinal plants with aphrodisiac potentials. Pharmacognosy Reviews.1(1) 49-56.

xxiii. Yakubu MT. and Quadri, AL. (2012). Garcinia kola seeds: Is the aqueous extract a true aphrodisiac in male wistar rats: African journal of traditional complementary and alternative Medicine. 9(4): 530-535. 